\title{
Perspectives on Stock Theft Prevention in the Selected Provinces of South Africa: Failures and Successes
}

\author{
Witness Maluleke ${ }^{1, *}$, Ntwanano Patrick Tshabalala ${ }^{2}$ and Aden Dejene Tolla ${ }^{3}$
}

${ }^{1}$ Department of Criminology and Criminal Justice, School of Social Sciences, Faculty of Humanities, University of Limpopo (UL) - University of South Africa (UNISA), Department of Police Practice, College of Law, South Africa

${ }^{2}$ Department of Criminology and Criminal Justice, School of Social Sciences, Faculty of Humanities, UL, South Africa

${ }^{3}$ Lecturer, Criminology and Forensics Studies Discipline (CFSD), University of KwaZulu-Natal (UKZN), South Africa

\begin{abstract}
Residents of Limpopo (LIM) and KwaZulu-Natal (KZN) Province are witnessing higher rates of stock theft, with the inhabitants of the selected communities living in fear for the prevention of this scourge. This study explores the extent of this crime in the selected areas of LIM and KZN, considering contributory factors, determining the relationship between the South African Police Service Stock Theft Units (SAPS STUs) and other relevant stakeholders, as well as looking at existing strategies (And their failures and successes) in responding to this crime effectively. A qualitative research approach coupled with Non-probability: Purposive sampling was used in this study. The targeted population consisted of 113 participants. For data collections, Focus Group Discussions (FGDs), Key Informant Interviews (KIIs), and Observation Schedules were adopted. lack of appropriate preventative measures has led to rise of stock theft, it was, therefore, discovered that both the affected livestock farmers and members of the community lost confidence toward the police, Besides, the perspectives on stock theft prevention in LIM and KZN reflect a greater challenge, with inadequate solutions present, since the current preventative measures are ineffective. Thus, understanding stock theft phenomenon is critical to its prevention as the sector of livestock in South Africa is the contributory key to the value of the agricultural economy.
\end{abstract}

Keywords: Agricultural economy, Failures, LIM Province, KZN Province. Perspectives, Stock theft prevention, Successes, South Africa.

\section{INTRODUCTION AND PROBLEM FORMULATION}

The backbone and a source of political and social influence to numerous rural communities across South Africa is upon livestock farming. In addition, livestock symbolise prosperity and prestige, provide an important source of wealth, food, income, social identity, recognition, pride and status. Livestock, such as Cattles' are of fundamental value since they are not only a source of food, but also crucial for social capital, which is essential for distinct negotiations as well as social investment in various rural communities. Livestock is regarded as a "living wealth" in rural communities because these animals mostly sustain and furnish source income to numerous rural communities. Livestock farming significantly contributes to the livelihoods of people residing in the rural areas of developing countries (Maluleke, 2020a).

However, researchers, academics, and scholars within the field of 'Criminology and Criminal Justice System (CJS)' have given less attention to or neglected

*Address correspondence to this author at the Department of Criminology and Criminal Justice, School of Social Sciences, Faculty of Humanities, University of Limpopo (UL) - University of South Africa (UNISA), Department of Police Practice, College of Law, South Africa; E-mail: witness.maluleke@ul.ac.za stock theft, as rural property-related crime over the past years (Coleman, 2011; Donnermeyer \& DeKeseredy, 2014; Maluleke, 2016, Maluleke, 2018, Manganyi, Maluleke \& Shandu, 2018, National Stock Theft Prevention Forum - NSTPF, 2019, and KwaZulu-Natal KZN Department of Community Safety and Liaison KZN DCSL, 2008). According to Minnaar (2016), the "mainstream criminology has, for the most part, ignored and neglected the development and building of a distinct theory of crime to address the challenges of rural crimes." Amongst the global issues that urgently need attention are crimes committed in the agricultural sector. Lack of attention to rural crimes within academia and the entire CJS for decades has raised concerns to Social scientists (Clack, 2013; Clack \& Minnaar, 2018; and Donnermeyer \& DeKeseredy, 2014).

Available studies on stock theft have only focused on the conventional methods to prevent stock theft. However, no study has been done on the combination of the conventional methods and available technologies to prevent this crime in the selected rural areas of LIM and KZN Provinces respectively.

Considerably; rural crimes still pose unique and complex problems to local and international spheres 
(Smith \& McElwee, 2013). The seminal research has been carried out on the effect of stock theft from an economical and preventative perspective, including factors that contribute to this crime, (Bunei, Rono \& Chessa, 2013; Khoabane \& Black, 2014; and Lombard, 2015). However, understanding prevention measures in the LIM and KZN Provinces respectively have has not been given the same attention. Whereas, in some other available studies, attention was on policing, financial and economic perspective regarding this crime (Abbas, Muhammad, Raza, Nazir \& HörethBöntgen, 2014; Bunei, Rono \& Chessa, 2013; Bunei, McElwee \& Smith, 2016; Dzimba \& Matooane, 2005; Khoabane \& Black, 2009; Khoabane \& Black, 2014; Clack, 2014c; Eloff, 1988; and Lombard, 2015).

It is presented that this study is timely, as the importance of stock theft crimes committed across the selected rural communities of South Africa keeps on increasing. The extent of this crime is not comprehended by the CJS or the academia in large. Therefore, it is hoped that this study can breached a gap and foster relationship between identified, relevant stakeholders to prevent stock theft through the use of available technologies, combined with the conventional strategies in the LIM and KZN Provinces.

Statiscally; The SAPS Crime Statistics (2021) shares the following reported cases of stock theft in the LIM and KZN Provinces, as depicted in Table 1; from these statistics, this crime increased drastically and unstable in the 2019/200 and 2020/2021 financial years nor reporting periods, this indicates that this crime is obviously becoming an international and local growing challenge, which is more multifaceted in nature, than a simple property-related crime, as other scholars confirmed.

In support of the provided statistics in Table 1, it can be confirmed that more than 14,000 Cattle are reported stolen, ending-up in 'Abattoirs, Butcheries' and on plates of unsuspecting South Africans. The current value chain is undisturbed, also fueling economic sabotage, requiring collaborative efforts by the local
SAPS STUs and other relevant departments to succor in the trailing, locating, marking and motility of livestock, Pijoos (2020). Furthermore, between July and September of 2020, approximately 7,339 stock theft cases were reported nationwide. Over 26,300 Sheep were also reported stolen, eNews Channel Africa [eNCA] (2020). While acknowledging that stock theft, as a rural crime, is seldom researched. Therefore, this study addresses the perspectives on stock theft prevention in the selected South African provinces to highlight the current successes and failures regarding this crime, as a precise rural crime that remains a conundrum to both rural South Africans and its transnational counterparts. Dean (2020) highlights that in the financial year 2018/2019, R1,2 billion of Cattles, Sheeps and Goats were stolen only in South Africa, NSTPF (2019).

It is also revealed that this table applied to the value of animals stolen and did not account for additional costs such as the judicial processes, recovery costs, farmer costs, and policing, among others. Moreover, 30 000 livestock were also reported stolen during this period. Besides, the value of the Cattle that were stolen was approximately R900 million (Constituting about R200 million worth of stolen Sheep and R100 millions of Goat). The major losses that were reported to the police transpired in KZN Province, where the most Cattle were stolen; followed by the Eastern Cape (EC), where the target was generally Sheep; and thereafter the Free State (FS), where both Cattle and Sheep were targeted by thieves. In support to this submission; Maluleke (2020b) submits that stock theft still remains one of the biggest obstacle grappling agricultural sector. All provinces across South African provinces are mostly affected by this priority crime, it is also touted as a more severe threat in regions that are neighboring other countries, such as the EC, FS, KZN, North West (NW) and Mpumalanga (MP) Provinces.

Subsequently, Chelin (2019) delivers that the most crucial challenge that remain is that only $20 \%$ of stock theft cases are reported across South Africa, connoting that the actual table of this crime is unknown. This

Table 1: Stock theft Statistics in the Limpopo Province, KwaZulu-Natal Province and National Focus

\begin{tabular}{|c|c|c|c|c|c|c|}
\hline $\begin{array}{c}\text { 2020/2021 first quarter statistics - } \\
\text { [April - June] }\end{array}$ & $\begin{array}{c}\text { 2020/2021 second quarter statistics } \\
\text { [July - September] }\end{array}$ & \multicolumn{2}{c|}{$\begin{array}{c}\text { 2020/2021 third quarter statistics } \\
\text { [October - December] }\end{array}$} & $\begin{array}{c}\text { Overall stock } \\
\text { theft statistics }\end{array}$ \\
\hline LIM & KZN & LIM & KZN & LIM & $\begin{array}{c}\text { KZN } \\
\text { 2019/2020 }\end{array}$ \\
\hline \hline 561 & 1679 & 530 & 1783 & 556 & 2018 & 28418 \\
\hline
\end{tabular}

SAPS Crime Statistics (2021) 
crime is seldom reported owing to the absence of trust in the SAPS. Moreover, this crime is becoming a global phenomenon, for instance; approximately $85 \%$ of stock theft is not reported in the United States (US), and) the table is at about $87 \%$ in the United Kingdom (UK). Most stock theft-related crimes are committed resulting from the greed by organised syndicates [of the almost 30 000 cases of stock theft recorded in the 2018/2019 financial year, approximately $87 \%$ involved some form of organised crime] as opposed to a crime of need by poverty-stricken individuals trying to survive. Dean (2020) mentions that the threat of growing transnational organised crime concerning stock theft is posed by syndicates who are progressively stealing Cattle in South Africa, taking them over the border of Lesotho for a cooling-off period, and then selling them back to South Africa.

It is proposed by researchers and investigators that stock theft is no longer limited to just stealing for sustenance, it has, therefore, advanced into an organised crime whereby crime syndicates are thought to be accountable for stealing enormous numbers of livestock (Clack, 2013; KZN DCSL, 2008; and Oosthuizen, 2010).

Therefore, the objective of this paper is to explore perspectives on stock theft prevention in the designated provinces of South Africa. This was done by looking closely at the effectiveness of current strategies of policing this crime to clear determine exiting failures and successes.

\section{BRIEF LITERATURE REVIEW}

SAPS National Crime Prevention Division (NCPD) held a National Rural Safety Conference (NRSC) from 23 to 25 of October 2001 in Midrand, Gauteng (GP) Province of South Africa, to furnish strategies aimed at preventing stock theft in South Africa at 'National level' and to amended the then socio-economic developments as they were mentioned to assist in the prevention of stock theft, while developing the capability to prevent the occurrence of this crime and to further implement strategies for developing rural areas across the country. So, this scourge can also be committed towards the subsistence farmers, further induce susceptibility and maximising poverty (KZN DCSL, 2008).

Furthermore, represented countries on the initial 'Southern African Regional Conference on Stock Theft' hosted from 7 to 10 May 2002 in Pretoria; by the six
Secretariat of the Southern African Regional Police Chiefs Co-operation Organisation (SARPCCO) coincided on the commitment to provide a guiding principle to control the mobility of livestock. Additionally, the usage of Deoxyribonucleic Acid (DNA) technology was further conferred to succour the identification of individual animals (Maré \& Schutte, 2012:60 and Geldenhuys, 2010).

Burger (2007) shares that stock theft can be monitored exerting proactive approach to policing can hinders the possible culprit from engaging in a particular criminal act at a precise location and time. In this sense, the police's view is that this crime can be perceived as "directly preventable" by the police activities. Therefore, stock theft is a crime, which is practically policeable as it can be prevented, and, thus, can deterred by an intensification of conventional policing (I.e. Visible patrols at the precise time, and location; the deployment of police officials in uniform; police warnings to the public; roadblocks; stop-andsearch actions; and cordon-and-search operations).

Moreover, Geldenhuys (2010) postulates that within the time frame of three years (2007 to 2009), the focused was rested upon the arrangement of the SAPS STUs by the police. So, they revised the related Units' locations, to decide whether they were conveniently present to the service areas on this regard. Regions with the drastic upsurge of stock theft were also observed to establish STUs, encompassing Greytown, in KZN and Giyani, in LIM Province. The 'Special Stock Theft Courts' and resurrection of 'Rural Safety Unit' are extremely required to enhance current the legislation and permit stiffer fines and sentences for stock thieves.

In an attempt to prevent this crime, operations are staged, notably; 'Operation Charlie' was viewed as one of the preventative measures that could be effectively applied by the SAPS, in conjunction with neighbouring countries, to prevent, and combat stock theft, Hennop, Jefferson and Mclean (2001). It was initiated on the $\mathrm{EC/Lesotho}$ border in early 1996. This operation is still on-going in the Rhodes area, with huge success, and stock theft has dropped significantly in this area. Containers were erected in this area, and are used as observation posts (Geldenhuys, 2010).

Furthermore, 'co-operation and communication' were established in respond to this crime to intensify the international and regional partnership, and cooperation. Thus, the Border Police were represented on different committees, forums, and organisations, 
such as the District Liaison Committees (DLC) on the Lesotho border, the SARPCCO, as well as several bilateral and trilateral forums between South Africa and some of its neighbours, including Botswana, and Mozambique (SAPS, 2002).

In the selected rural areas of LIM Province [Giyani Policing Area - GPA in this regard]; the Mahlasegi Cluster Livestock Forum was formed on 22 August 2012. It comprises of Malamulele, Hlanganani, Sekgosese, and Giyani to act as operational areas, with the objectives of uniting and advising the community of livestock farmers to be involved in the development of their areas, with small and large stock and ensure that this community advise and encourage community participation in the prevention of stock theft, and veld fires, among others.

Furthermore, the SAPS 'Operation Thiba' was inducted in the LIM Province in January 2004, with collaborations of the local Department of Police, Farmers' Organisations/Unions, Departments ofHealth (DoH), Department of Agriculture, Forestry and Fisheries (DAFF) and Safety and Security, Chiefs and Indunas to combat stock theft across the province. This was, however, introduced to ensure meticulously investigations of cases, including theft of Goats, Sheep and Cattle, through the involvement of the community, and more rigorous obedience with the appropriate legislatures, together with matters surrounding deficiency of fencing around grazing camps, unreported cases of stock theft and police corruption, unregistered and tampering with brand marks. stock theft reached extraordinary levels in LIM Province during 2001 and 2004.

The essence of livestock cannot be understated, because it represents the main source of family or individual wealth, social standing in the community, and a means to make capital to cover unforeseen emergencies for people residing in the villages (Mokale, 2006). This was followed by the SAPS Pilot's Cabin was initiated in 2006 to conduct 'Operation 22' based on stock theft, entitled: The 'Trouble Tracer of Wanted Persons.' This allowed other provinces to also conduct 'Project Gijima" in the same year. From 25-27 of August 2006 (SAPS Pilot's Cabin, 2006).

The KZN DCSL (2008) reveals that the KZN provincial stock theft combating operations include; 'Underberg / Himeville District Security Coordination Centre (Community Watch),' which coordinates security in this district. This ingenuity commenced as a
'Farm Watch' in 1995 when it changed its attention to providing services to the general community instead of serving only the farming sector, its name was altered to 'Community Watch.' On the other side; the 'Swartberg Stock Theft Prevention Association (SSPA)' functions in the Swartberg, Evatt and Ferndale regions. However, this area also covers Joyner's Gate, known as the provincial border between Jonathan's Gate and $E C$ and KZN, the border between Sehlabateba National Park and South Africa.

Furthermore, the 'KZN Agricultural Union (Kwanalu) Security Desk' was developed in May 1998 as a 'Security Desk' among others, was to assist with the implementation and monitoring of the 'Rural Protection Plan' in the KZN Province. Besides, the 'community policing project: Branding of Cattle at Ntunjambili, KZN' was introduced before the realisation the effects caused by stock theft on people's pockets in this province and Cattle owners in the Kranskop area of $\mathrm{KZN}$ have been as well suffering these effects at the hands of stock thieves. Cattle owners barely sleep at night because of fear and worry that their Cattle will continue to be stolen, albeit the arrests were made by the Greytown SAPS STU, (Geldenhuys, 2012a, and Geldenhuys, 2012b).

Another intervention of preventing stock theft rests in the 'provincial' sphere, where the and Provincial Stock Theft Forum (PSTF) in all nine South African provinces to co-operate with the National Stock Theft Forum (NSTF) to prevent this crime in an organised manner. To this course, the disciplines under the Red Meat Procedures Organisations (RPO) are represented in the NSTF, they are responsible for the Secretariat of the NSTF and the provincial RPOs of most of the nine provinces is handle associated matters; this includes the all the affiliated procedures and DAFF disciplines Maré (2012).

Consequently, the processes and channels for addressing stock theft at community levels are supported by Geldenhuys (2010:39-41) by providing the preceding preventative measures, in line with the processes of addressing this crime effectively in South Africa:

- Livestock owners' responsibility: To protect livestock from criminals, while focusing on a few basics of preventing this crime.

- Importance of proper fencing: Ensuring suitable sustenance of fences, patrolling and 
keeping all fences and gates in correct working order by livestock farmers to protect livestock.

- Marking of livestock: DAFF' strategy to curb stock theft also use The Animal Identification Act (No. 6 of 2002) to prescribes identification marks for tracing the owner as the initial line of defence against sock theft. Consequently, livestock are expected to be marked based on this Act.

- Regular counting of livestock: The livestock owners must try to count their animals regularly and keep an updated stock register to control of their livestock.

- Regular patrols serve as a deterrent: Livestock owners must patrol paddocks regularly to serve as a deterrent to potential stock thieves.

- Know your employees: When livestock owners consider appointing new employees, the owner must locate the applicant's previous employers, and find out why they left their former jobs. to determine whether the applicant has a criminal record, and determine the nature of transgressions, enquiries can also be made at the SAPS.

- Moving animals: Section 8 of the Stock Theft Act (No. 57 of 1959) indicate that no person shall transport, convey, nor relocate any livestock, or produce, if such individual is not entitled to or not the rightful owners, at any public road, unless otherwise possess the rightful documentation "removal certificate" given by the owner/manager of the livestock.

- The omnipresence of the police: Livestock owners must become involved in a farm watch system within their respective region. If such a system does not exist, it is a good idea to establish one. The police cannot be expected to protect everyone's property, and the community must help. A farm watch system ensures good communication, and regular, physical patrolling $24 / 7$, deters stock theft.

Additionally; The local SAPS members are often asked what livestock owners could do to prevent stock theft. Apart from the tips already provided, livestock owners could also exercise the following measures: Keep Sheep in a Kraal, as close to the farmhouse as possible; Invest in proper guard dogs at the kraal; Keep ostriches (or geese, for noise) in paddocks, as it is known that they are a good deterrent against potential stock thieves; Avoid routine; and Have employees move around on the farm, and pay attention to irregularities, to inform the livestock owner of such irregularities, Geldenhuys (2010).

Geldenhuys (2010) further opines that it is fundamental to have a healthy relationship between the SAPS, livestock owners, their employees. SAPS is expected to provide a professional service to the community concern, while on the other side, livestock owners are as well expected to play their role. By so doing, it can be convenient to prevent this crime. It is of paramount importance to solve and reduce the variety of crimes related to stock theft to present based on a global economic trends and capital incentives to obtain a sustainable, profitable and food security and the emotional effects it contains the agricultural community (NSTPF, 2019).

As a recourse; Maluleke (2018) avers that different technologies (As previously mentioned) and DNA technology was intended to revolutionise modern science and to intensify conventional approach to preventing this crime by operationalising the CJS. Nevertheless, most livestock farmers value the use of technology in preventing stock theft is imprecise. As an alternative, they return to conventional approaches like brand-marking and tattoos. These conventional methods have not offered an ongoing resolution to the peril of South African stock-theft.

\section{METHODS AND MATERIALS}

This study adopted exploratory and descriptive research designs, coupled with a qualitative research approach to purposively select participants to inspect and evaluate, the definite perceptions of the selected participants on prevention of stock theft to understand the current failures and successes. The study locations were confined to the selected areas of $\mathrm{KZN}$ (Ladysmith, Bulwer - Pietermaritzburg, and Utrecht Newcastle) and in LIM Province [GPA: Giyani inner city, Xikukwana and Makosha villages (Ward 14) and in FGDs, in-depth interviews with KIls, and stock theft courtroom observation schedules were exerted for collection of data.

The target groups comprised of the follows: Community Policing Forums (CPFs) managers (4:2 from each village - rural areas outside the city); Community members (12:6 from each village - Rural areas outside the city); Mopani District officials (2: Community Researcher and a Community Liaison 
Officer); FGDs 1: SAPS officers attached to the local police station (8 - take out from the inner city area); FGDs 2: leaders from the local Faith-Based Organisations [FBOs] (4:2 from each village); and FGDs 3:prominent local farmers (20:10 from each village - Rural areas outside the city). Natural Resource Management managers) (2); and Land and Infrastructure; Community Safety and Liaison Officer); and officials from Giyani Municipality (2: Occupational Health and Safety Officer; KIls were steered in the inner city consisting of participants from the Giyani SAPS STU officers (7); DAFF (Veterinary Services; Giyani Magistrates' Court personnel (3; Senior Prosecutor, Control Public Prosecutor; Court Interpreter). Consequently, the overall participants selected were 64 participants on the bases of their stock theft knowledge and the measures utilised to combat this crim in the GPA of LIM Province.

The sample size constituted 49 participants in the KZN Province, with appropriate stakeholders who participated in an arrangement of FGDs and KIls were as follows: Two DAFF staff (Assistant Directors: One (01) SAPS STU provincial Co-ordinator (KII); $38 \mathrm{KZN}$ SAPS STUs members (14 employing KIls; Animal Technicians and Animal Production officials) (KIls); and 24 in several FGDs); five Anti-Stock Theft Association managers (KIIs); and eight livestock farmers (FGDs); three CPF members/chairpersons (KIls); Inclusively, this study encompassed 113 participants selected from Two provinces [LIM and KZN] South Africa, mainly concentrating on rural areas [Rural livestock farmers]. For data analysis; the researchers frequently red the data to hold up the perception from the selected participants on this subject [Content Analysis - CA]. So, this was accomplished through generating hidden written transcripts of the participants' replies throughout KIls and the FGDs to produce themes. The definite words articulated by the participants were written down verbatim (word-for-word) (Matlala, 2012).

\section{STUDY FINDINGS AND DISCUSSIONS}

These findings of this study are arranged in terms of the study objective, what the participants shared with the researchers was thematically presented in this section.

EXPLORING PERSPECTIVES ON STOCK THEFT PREVENTION IN THE SELECTED PROVINCES OF SOUTH AFRICA: FAILURES AND SUCCESSES

Insufficient coverage of the study objective was received. It was quite revealing to find that the existing preventative measures exerted in the LIM and UKZN designated regions by the livestock farmers, SAPS STUs and other appropriate stakeholders, with regarding stock theft are unsuccessful. This study discovered that these stakeholders do not possess an appropriate capability to answer regarding this crime. The participants share the same response by articulating that the SAPS STUs do not possess an aptitude to detect the challenges related to stock theft. It was also revealed SAPS STUs do not possess effective policies nor strategies to co-ordinate the prevention of stock theft in the designated areas.

The participants indicated that the SAPS STUs consist of distinct challenges that interfere with their police work. However, these Units consist of the of insufficient personnel; So, there is a necessity for additional personnel to be assigned to the SAPS Satellite Units if available, precisely in the identified rural areas of GPA, as well as to the main Giyani SAPS STUs. This, however, also apply to the identified KZN Province regions. There should be recruitment, or retained at the Community Service Centre (CSC) of officers involved in the local police stations, and the additional officers at the police station level. Thus, they should, initially, undertake training for stock theft investigation.

This arrangement can, therefore, render investigators an opportunity at the local police station level to become acquainted with all aspects, regarding the stock theft investigation. A latter from SAPS STUs officers must be provided where applicable. This as a results can ensure the constant principle of an integrated technique. it is of paramount important to consider the remoteness, and the presence of informants at all time. It was suggested that this should be frequently discussed between the local police station Commanders and the SAPS STUs Commanders.

It was, however, revealed that there is a need to work out how inadequate resources can proficiently be accomplished by the designated SAPS STUs. It seems that appropriate management is deficient to evaluate the available limited resources, and therefore, the unavailability of police vehicle as technical issue cannot be blamed to SAPS officials on the failure to engage stock theft operation. Noting that rural people resort to using alternative structures, such as the 'Livestock Forums, 'and CPFs. There is a need to monitor, capacitate and assess those systems, to check whether they have an impact on, and adhere to, the 
measures intended at the cabbing stock theft. CPFs have to be invigorated and should establish a healthy environment for sector policing. There is a necessity for a mass mobilisation of community structures, and community-based organisations, to partake in social crime prevention, and to capacitate them on $\mathrm{m}$ of social crime prevention.

The performance of the Magistrates' court in the selected areas of LIM and KZN Provinces are known, by disposing of cases of stock theft. The Magistrates' Courts' efficacy to manage cases of stock theft cases are dubiously influenced by lack of understanding on the colours that the local people are adapted to utilising the practices of livestock farming and traditional markings. Consequently, the 'Customary Courts' is quoted as best-suitable in managing stock theft cases, as 'Indunas [Chiefs]' imbedded the power to preside over such cases with well understandings on this crime, have a reflective knowledge on the cases of stock theft and of livestock and

For a positive response; Knowledge Management (KM) should be implemented in the prevention of stock theft in South African rural communities, this should be undertaken as the first approach to combat stock theft

Table 2: Identified Themes of Failures and Successes

\begin{tabular}{|c|c|}
\hline Failures & Successes \\
\hline $\begin{array}{l}\text { Over-reliance on conventional methods of } \\
\text { policing this crime }\end{array}$ & $\begin{array}{l}\text { The use of other technological devices and DNA technology to police this crime are used } \\
\text { in some parts of South Africa, this act as an aid to the existing traditional methods [It is } \\
\text { highly advised for the livestock farmers to employ distinct technologies for proactive and } \\
\text { reactive policing of stock theft in combination with the conventional approaches] }\end{array}$ \\
\hline $\begin{array}{l}\text { Stock thieves' syndicates involved are } \\
\text { increasingly becoming more organised and } \\
\text { responding to stock theft peak times }\end{array}$ & $\begin{array}{l}\text { The South African governments, SAPS STUs and livestock farmers started to treat stock } \\
\text { theft as a serious criminal activity across the country. The increasing treads of stock theft } \\
\text { are noted during Christmas and Easter periods }\end{array}$ \\
\hline $\begin{array}{c}\text { A need for the creations of a Stock Theft } \\
\text { Forensic Laboratory (STFL) in the elected } \\
\text { provinces to evade the extended distances to } \\
\text { be travelled when submitting the DNA evidence } \\
\text { in Pretoria Cape Town and Port Elizabeth, other } \\
\text { than Animal Research Council (ARC), working } \\
\text { in partnership with the University of Pretoria } \\
\text { (UP) and other private institution to provide } \\
\text { necessary outcome swiftly to the affected } \\
\text { parties }\end{array}$ & $\begin{array}{c}\text { The SAPS administration reconsiders of a solitary usage of ARC laboratory as its } \\
\text { efficiency and capability are questioned }\end{array}$ \\
\hline $\begin{array}{l}\text { Lack of adequate research and intelligence on } \\
\text { stock theft }\end{array}$ & $\begin{array}{c}\text { Enhance research and intelligence on stock theft field as 'Rural Criminology' field } \\
\text { beginning to show footprints locally and internationally }\end{array}$ \\
\hline $\begin{array}{l}\text { Weak systems used during 'auctions and } \\
\text { shows,' porous border control measures and } \\
\text { lack of understanding the value of livestock }\end{array}$ & $\begin{array}{l}\text { Intensification of security checks at abattoirs, border controls, auctions, depicts and re- } \\
\text { addressing livestock movement scare potential offenders from taking advantage in this } \\
\text { setting while reconsidering the value of livestock. }\end{array}$ \\
\hline $\begin{array}{l}\text { Training, capacitation and resources available } \\
\text { for SAPS STUs staff members to swiftly } \\
\text { respond to stock theft scenes }\end{array}$ & $\begin{array}{c}\text { The clear understanding of stock theft trends and exercising precautions at farm levels in } \\
\text { the rural areas }\end{array}$ \\
\hline Improving reporting rates of stock theft cases & $\begin{array}{l}\text { Concentrated partnership-based, including interaction, collaboration, and information } \\
\text { exchange are exerted in some part of South Africa, precisely in the selected provinces }\end{array}$ \\
\hline $\begin{array}{l}\text { Inadequate evidence collection and witness } \\
\text { protection }\end{array}$ & $\begin{array}{c}\text { Local livestock farmers believe that each animal is exceptional, and that stock treatment } \\
\text { can result to different marks on each animals. Thus law enforcement officials to } \\
\text { prosecute stock thieves can effectively use these two facts. }\end{array}$ \\
\hline $\begin{array}{l}\text { High level of corruption where the local SAPS } \\
\text { members collude with the criminals to steal } \\
\text { stock }\end{array}$ & $\begin{array}{l}\text { In view of refining documentation, identification, Traceability System for South Africa - } \\
\text { LITS SA] and traceability [exerting the extended-waited Livestock Identification. }\end{array}$ \\
\hline $\begin{array}{l}\text { Lack of ownership identifications, controlling } \\
\text { and counting of livestock }\end{array}$ & $\begin{array}{l}\text { Proactively using livestock identification to serve as the first line of defence to ensure that } \\
\text { most stock theft cases are dealt with accordingly. Livestock are twice counted daily }\end{array}$ \\
\hline $\begin{array}{c}\text { Fear of reporting and testifying in court [Not } \\
\text { willing to form part of the perceived exhausting } \\
\text { criminal proceedings] }\end{array}$ & $\begin{array}{c}\text { The South African government is rising to the challenge of the current constraints on the } \\
\text { CJS }\end{array}$ \\
\hline Resorting in mob justice to police this crime & $\begin{array}{c}\text { Some livestock farmers keep peace and not accuse someone in the community nor } \\
\text { outside }\end{array}$ \\
\hline
\end{tabular}

Source: Researchers emphasis (2020-2021). 
across the selected provinces of South Africa, which contributes larger percentages to this crime, particularly in the selected rural areas of LIM and KZN Provinces respectively. It should be noted that for the purpose of this study, KM is should be accompanied by the enforcement of Animal Identification Act (No. 6 of 2002) and Stock Theft Act (No. 57 of 1959) as some of the conventional methods [Brand-marking and tattooing] and the involvement of other relevant stakeholders to police this crime; this should be enhanced and supported by the Criminal Law (Forensic Procedures) Amendment Act [No. 37 of 2013] (the "DNA Act"), and other related international Act, such as the World Organisation for Animal Health standards [OIE] standards, as well as other available modern technologies [Such as the Wireless Fidelity - Wi-Fi, Radio Frequency Identification - RFID, Wireless Sensor Node / Network - WSN, DNA technology and ZigBee.

Collaboration and sharing of knowledge among livestock farmers across South African in rural areas holistically and elsewhere [Other affected Townships and urban areas] can be improved by the KM. the need for $\mathrm{KM}$ in the livestock farming sector remains a common significant knowledge. However, it is still difficult to sustain livestock to various livestock farmers due to insufficient $\mathrm{KM}$ that adds to identified disappointments regarding this; as denoted in Table 2. It is very imperative to all livestock farmers; such as emerging, the stud, and commercial farmers from distinct regions to share their best practices within their respective jurisdictions and their operations should be integrated for the benefit of food security largely. This should be underpinned by capturing, creation, delivering and sharing of elusive information and knowledge among all livestock farmers.

Therefore, the KM practices relate to the best practices to intensify the productivity of livestock farming, and to sustain the relationship to combat, protect and prevent stock theft and livestock health to be facilitated effectively by the appropriate stakeholders. It envisaged that if $\mathrm{KM}$ can be implemented positively by these relevant stakeholders with an intent to maximise the quality and efficiency of stock theft combating strategies across these South African, rural areas and selected areas of LIM and $\mathrm{KZN}$; the use of the mentioned technologies and other available conventional methods can go a long way, this can also include animal identification techniques. This can enhance proper utilisation of this concept (KM) in terms of sharing and transferring best practices to prevent stock theft with the aid of the revolutionary collation of technologies, while addressing the existing complexities brought about by the conventional theftcombating strategies.

\section{CONCLUSION AND RECOMMENDATIONS}

Generally, the purpose of this study was to collect data on, and determine, the perceptions on the combating of stock theft in the selected areas of LIM and KZN Provinces; therefore, detecting dissatisfactions and successes experienced in these areas, given their insufficient measures in dealing with stock theft in the surrounding areas. It is found that this crime remains a complete credit to families of the selected provinces, precisely in the rural villages generally the policing regions, and the entire municipalities. Yet, the capability of the livestock farmers, local police and the community members' response, to this crime is presently unsuccessful.

From the analysed data; it is evident that stock theft is rife in the selected areas of LIM and KZN Provinces, and the available preventive measures against stock theft in these regions are inadequate, therefore, there is an extended way to go to completely eradicate it. These inefficiencies should be corrected, and some other measures, which could be exerted as recommendations include:

- Closer collaboration, interaction and information exchange: The Intelligence-led operations currently employed by the SAPS STUs need a radical, new approach, including nearer collaboration, interaction, and information conversation of the entire role-players in these provinces.

- $\quad$ Promoting greater awareness in the province and neighbouring countries: It is pivotal for the SAPS STUs in these provinces, to collaborate with the local SAPS, as well as the livestock forums, to promote greater stock theft risks and actions awareness. The community members' behaviour, livestock farmers, and other related stakeholders could be altered, to enable selfprotection, and assistance to alter the culture that accepts a certain level of stock theft crime in the selected rural communities.

This study revealed the dire need for the use of the combined methods (Technologies and conventional methods) to effectively prevent stock theft in the selected provinces of South Africa in the LIM and KZN 
Provinces specifically. The selected areas in these provinces were chosen as learning grounds, from which shortfalls and outcomes of previous methods employed to combat stock theft were used to inform current research works and to improve future works in the use of the identified methods. The consulted methods can be easily accessible by means of the establishment of effective partnerships between the CJS and other relevant stakeholders in this sector and also the use of communal intervention systems to break silo culture and isolation existing procedures to move into a collaborative approach towards stock theftcombating strategies. It is important to simultaneously establish mechanisms to transfer $\mathrm{KM}$ and share strategies, including the integration of conventional methods with available technologies, sharing the results of preliminary investigations to inform stakeholders of court procedures.

\section{REFERENCES}

Abbas, T., Muhammad, Y., Raza, S., Nazir, A and Höreth-Böntgen, DW. 2014. Some facts and issues related to livestock theft in Punjab province of Pakistan: Findings of series of cases. Berliner und Münchener Tierärztliche Wochenschrift, 127:1013.

Bunei, EK., McElwee, G and Smith, R. 2016. From bush to butchery: Cattle rustling as an entrepreneurial process in Kenya. Society and Business Review, 11(1):46-61. https://doi.org/10.1108/SBR-10-2015-0057

Bunei, E. K., Rono, JK and Chessa, SR. 2013. Factors influencing farm crime in Kenya: Opinions and experiences of farmers. International Journal of Rural Criminology, 2(1):75-100. https://doi.org/10.18061/1811/58846

Burger, F.J. 2007. Strategic perspectives on crime and policing in South Africa. Van Schaik Publishers: Hatfield.

Chelin, R. 2019. Organised crime moves in on South Africa's livestock industry. November 19, Institute of Security Studies [Online]. Available at: https://www.dailymaverick.co.za/ article/2019-11-19-organised-crime-moves-in-on-southafricas-livestock-industry ...

Clack, W. 2013. The extent of stock theft in South Africa. Acta Criminologica: Southern African Journal of Criminology, 26(2):77-91.

Clack, W. J. 2014. The role of social media in livestock theft: A case study. Acta Criminologica: Southern African Journal of Criminology: Special Edition: Research and Application in Criminology and Criminal Justice, 1:101-177.

Clack, W and Minnaar, A. 2018. Rural crime in South Africa: An exploratory review of 'farm attacks', and stock theft as the primary crimes in rural areas. Acta Criminologica: Southern Africa Journal of Criminology, 31(1):103-135.

Coleman, A. 2011. Stock theft has been declared a priority crime in the National Rural Safety Strategy. Farmers Weekly, 29 July:1. Available at: https://www.farmersweekly.co.za/ opinion/by-invitation/saps-rural-safety-strategy-reviewunderway/.

Constitution of Mahlasegi Cluster Livestock Forum. 2012. Giyani Cluster: Limpopo Province.

Dall, N. 2020. The cattle massacre that haunts South Africa. Available at: https://www.ozy.com/true-and-stories/the-cattlemassacre-that-haunts-south-africa/88717/.
Dean, S. 2020. Stock theft - Over R1,2 billion in livestock theft reported in 2018/2019. Farmer's Weekly, 17 January, 24.

Donnermeyer, JF and DeKeseredy, WS. 2014. Rural criminology: New directions in critical criminology. Routledge: Oxon. https://doi.org/10.4324/9780203094518

Dzimba, J and Matooane, M. 2005. Stock theft and human security: A case study of Lesotho. Pretoria: Institute for Security Studies.

Eloff, CC. 1988. Stock-theft in the Conquered Territory during the 19th century. Historia, 33(1):53-68.

eNews Channel Africa [Online]. 2020. Stock theft more serious than it seems: Expert. November 16. Available at: https://www.enca.com/news/stock-theft-more-serious-itseems-expert.

Geldenhuys, K. 2012a. Community policing project: Branding of cattle at Ntunjambili, KZN. Stock Theft workshop in Pretoria. Servamus - Community Based Safety \& Security Magazine, June: 41-41.

Geldenhuys, K. 2012b. Stock theft workshop in Pretoria. Servamus Community Based Safety \& Security Magazine, June: 40.

Geldenhuys, K. 2010. Stock theft and what owners can do to protect their stock. Servamus - Community Based Safety \& Security Magazine, November: 38-41.

Hennop, E, Jefferson, C and Mclean, A. 2001. The challenge to control South Africa's borders and borderline. Monograph No. 57, August.

Khoabane, S and Black, PA. 2014. On the economic effects of livestock theft in Lesotho: An asset-based approach. Journal of Development and Agricultural Economics, 4(5):142-146.

Khoabane, S and Black, PA. 2009. The effect of livestock theft on household poverty in developing countries: The case of Lesotho. Stellenbosch Economic Working Papers. 02/09:1-8.

KwaZulu-Natal Department of Community Safety and Liaison. 2008. Stock theft in KwaZulu-Natal. KZN Department of Community Safety and Liaison: Pietermaritzburg.

Lombard, WA. 2015. The financial impact of sheep theft in the Free State province of South Africa. Unpublished Magister Scientiae Agriculturae. Faculty of Natural and Agricultural Sciences, Department of Agricultural Economics. University of the Free State: Bloemfontein.

Lombard, WA., van Niekerk, HN., van Rooyen, FM and Ogundeji, A. 2017. Factors Affecting Sheep Theft in the Free State Province of South Africa. Molecular Diversity Preservation International and Multidisciplinary Digital Publishing Institute: Basel, Switzerland. https://doi.org/10.3390/books978-3-03842-331-7-7

Manganyi, FM., Maluleke, W and Shandu, SN. 2018. An examination of co-operative strategies towards policing stock theft in the KwaZulu-Natal Province. Acta Criminologica: Southern African Journal of Criminology, 31(4), Special Edition: Rural crime, 97-122.

Maluleke, W. 2020. Proposing a new Deoxyribonucleic Acid technology conceptual framework in combating stock theft in South Africa: Empirical evidence. Journal of the Social Sciences, 48(4), 2693- 2716.

Maluleke, W. 2018. The integration of conventional and technological methods in combating stock theft by selected stakeholders in the KwaZulu-Natal Province. Acta Criminologica: Southern African Journal of Criminology, 31(4), Special Edition: Rural crime, 123-146.

Maluleke, W. 2016. The use of Deoxyribonucleic Acid technology in combating stock theft in South Africa. Unpublished Doctor Technologiae. Faculty of Humanities, Department of Safety and Security Management. Tshwane University of Technology: Soshanguve South Campus, Pretoria.

Maluleke, W. 2020. The value of Deoxyribonucleic Acid technology in combating stock theft in the KwaZulu-Natal Province: Lessons for South African Police Service Stock Theft Units. Journal of the Social Sciences, 48(4), 2858- 2875. 
Marè, J. 2012. National Stock Theft Forum report. Red Meat Procedures Organisation Congress. Available at: https://www.rpo.co.za/wp_content/uploads/2016/04/Stock_Th eft_Report_-_September_2014.pdf.

Maré, J and Schutte, G. 2012. Livestock theft figures. Stock farm: Pretoria.

Matlala, MM. 2012. The use of the Automated Fingerprints Identification System to improve the quality of service rendered by the South African Police Service in the East Rand. Unpublished Magister Technologiae: Police Science dissertation. University of South Africa: Pretoria.

Minnaar, A. 2016. Research, theory and a developing criminology for rural crime. Acta Criminologica: Southern African Journal of Criminology, 29(1): i-v.

Mokale, A. 2006. Provincial Stock Theft Co-ordinator - Operation Thiba to Combat Stock Theft in Limpopo. SAPS National Head Office: Impumelelo.

National Stock Theft Prevention Forum. 2019. Press release Livestock theft crime statistics. NSTPF: Persequor Park.

Oosthuizen, O. 2010. South African Police Service: Stock Theft Unit information brochure, Stock Theft Act, 1959 (Act No. 57 of 1959). Available at: http://www.kwanalu.co.za/upload/ files/SAPSStockTheftBrochure.pdf.
Pijoos, I. 2020. \#CrimeStats: Stock theft 'serious,' with 26,000 sheep stolen in 3 months. November 13, Sunday Times [Online]. Available at: https://www.timeslive.co.za/news/southafrica/2020-11-13-crimestats-stock-theft-serious-with-26000sheep-stolen-in-3-months ...

Smith, R and McElwee, G. 2013. Confronting social constructions of rural criminality: A case story on 'illegal pluriactivity' in the farming community. Sociologia Ruralis: European Society for Rural Sociology, 53(1):112-134. https://doi.org/10.1111/j.1467-9523.2012.00580.x

South African Police Service (SAPS) Pilot's Cabin. 2006. Stock theft Volume 5, issue 2. September: Available at: http://www.rpol.co.za/files/stock_theft.pdf.

SAPS Crime Statistics. 2021. Crime statistics 2019/2020. Available at: https://www.saps.gov.za/services/crimestats.php

SAPS Crime Statistics. 2021. First quarter crime statistics 2020/2021. Available at: https://www.saps.gov.za/ services/crimestats.php.

SAPS Crime Statistics. 2021. Second quarter crime statistics 2020/2021. Available at: https://www.saps.gov.za/services/ crimestats.php.

SAPS Crime Statistics. 2021. Third quarter crime statistics 2020/2021. Available at: https://www.saps.gov.za/services/ crimestats.php.

https://doi.org/10.6000/1929-4409.2021.10.121

(C) 2021 Maluleke et al.; Licensee Lifescience Global.

This is an open access article licensed under the terms of the Creative Commons Attribution Non-Commercial License (http://creativecommons.org/licenses/by-nc/3.0/) which permits unrestricted, non-commercial use, distribution and reproduction in any medium, provided the work is properly cited. 